\title{
Realization of the key aspects of the right to adequate housing in affordable housing programs in Egypt
}

\author{
Nahla Mahmoud Hafez ${ }^{1,2^{*}}$, Rowaida Reda Kamel ${ }^{1}$, Doaa Mahmoud Elsherif ${ }^{2}$ and Rania Ibrahim Nasreldin ${ }^{1}$
}

\author{
* Correspondence: nahla.hafez@ \\ hbrc.edu.eg \\ ${ }^{1}$ Department of Architecture, \\ Faculty of Engineering, Cairo \\ University, Cairo, Egypt \\ ${ }^{2}$ Architecture and Housing Research \\ Institute, Housing and Building \\ National Research Center, Giza, \\ Egypt
}

\begin{abstract}
The realization of the right to adequate housing is a critical issue that countries seek to achieve through affordable housing projects. However, there is a discrepancy in fulfilling the right to adequate housing between countries, which has surfaced the dilemma of defining adequate housing. In this respect, scanning relevant literature figured out seven key aspects to meet the right to adequate housing. Using a questionnaire launched to experts in the field, they figured out to what extent the seven aspects have been realized in the affordable housing programs in Egypt. The results showed a significant percentage of realization of the seven key aspects of the right to adequate housing. The findings showed an apparent variation in the completion of the seven key aspects, which decision-makers can improve at different scales with the progression of the programs. Future research can build on this direction to consider aspects like accessibility and cultural adequacy of these programs.

Keywords: The right to adequate housing, Security of tenure, Accessibility, Habitability, Affordability, Cultural adequacy
\end{abstract}

\section{Introduction}

Affordable housing programs are the traditional approach for governments to make housing accessible for low-income groups. Still, the affordable housing production systems struggle to overcome the widespread housing crises in developing countries, although they all aim to deliver economic and social benefits for low-income groups. It is estimated that more than one billion people live in substandard housing, and the number of homeless people is more than 100 million worldwide ([1], P. 2).

In 1948 with the adoption of the universal declaration of human rights, the right to adequate housing has been recognized as one of the essential elements of the right to an adequate standard of living [2]. Despite the government's attempts to realize the right to adequate housing by providing capabilities and resources, the right to adequate housing requires clear aspects for its realization, which made the United Nations Committee on Economic, Social, and Cultural Rights (UN-CESCR) studies of the aspects of

(c) The Author(s) . 2021 Open Access This article is licensed under a Creative Commons Attribution 4.0 International License, which permits use, sharing, adaptation, distribution and reproduction in any medium or format, as long as you give appropriate credit to the original author(s) and the source, provide a link to the Creative Commons licence, and indicate if changes were made. The images or other third party material in this article are included in the article's Creative Commons licence, unless indicated otherwise in a credit line to the material. If material is not included in the article's Creative Commons licence and your intended use is not permitted by statutory regulation or exceeds the permitted use, you will need to obtain permission directly from the copyright holder. To view a copy of this licence, visit http://creativecommons.org/licenses/by/4.0/. The Creative Commons Public Domain Dedication waiver (http://creativecommons.org/publicdomain/zero/1.0/) applies to the data made available in this article, unless otherwise stated in a credit line to the data. 
that right consider the definition of the key aspects of the realization of the right to adequate housing; these key aspects are the security of tenure, availability of services, adequate location, affordability, habitability, accessibility, and cultural adequacy ([1], P. 5-6).

The realization of the seven key aspects in the housing strategy is among the factors that support obtaining housing at an appropriate cost, adequate location, safe building structures that meet the needs of the residency, to fulfill the residents' social and cultural needs, to ensure legal security of tenure, and ensuring the access to adequate housing for all groups without any sort of discrimination. Therefore, the research aims to evaluate the realization of the key aspects of the right to adequate housing in the affordable housing programs in Egypt to figure out to what extent the seven aspects have been realized and which can improve at affordable housing programs in the future.

\section{Methods}

The paper aims to evaluate the realization of the key seven aspects of the right to adequate housing in affordable housing programs in Egypt. The paper methodology consists of three parts. The first part discusses the right to adequate housing on the international and national levels and the seven key aspects of its realization. The second part reviews the affordable housing programs in Egypt by analyzing their four phases: rent projects from 1952 to 1981, various ownership projects from 1982 to 2005, the national housing program from 2005 to 2011, and social housing programs from 2011 till now. The third part analyzes the realization of the seven key aspects in the four phases of the affordable housing programs in Egypt using experts' questionnaires and structured interviews for a diverse sample of 57 researchers and experts in the field of housing, and representatives of government agencies related to the housing field. The experts' questionnaires included 72 questions divided into seven sections (analogy of the seven key aspects), The first section includes questions on the aspect of legal security of tenure, the second section deals with the aspect of availability of services and infrastructure, and the sections from 3 to 7 deal with the key aspects of affordability, habitability, accessibility, location, and cultural adequacy. All the sections cover the four phases of affordable housing programs in Egypt. Based on experts' results, which include the seven key aspects during the 72 questions, it was possible to calculate the number of points collected for each aspect through the use of Microsoft Excel. Accordingly, it was possible to compare the fulfillment in the seven key aspects between the four phases of affordable housing programs in Egypt.

\section{The right to adequate housing}

The right to adequate housing has been mentioned in many international charters and treaties such as the universal declaration of human rights in 1948, the United Nations declaration of the rights of the child in 1951which provides the child's right to adequate housing, the international law which recognized the right to adequate housing as in article 25(1) of the universal declaration of human rights, and the basic international human rights conventions which recognized the right to housing in the international covenant on economic, social, and cultural rights in 1966 in article 11 ([2], P. 1-11). Egypt is one of the countries that signed this covenant and ratified it in 1982 ([3], P. 43). 
In 1987 the general assembly of the United Nations declaration emphasized the need to take the necessary actions at the national and international levels to promote the right of the adequate standard of living for all, including adequate housing ([4], P.234235), then in 1991, the seven key aspects of the realization of the right to adequate housing were declared in general comment No. 4 to resolve the problematic definition of the right to adequate housing and the owners of that right [1]. Figure 1 shows the timeline for the concept of the right to adequate housing.

\section{Recognition of the right to adequate housing on the national and international levels}

The basic international human rights treaties affirmed the necessity of every person's right to enjoy adequate housing ([2], P. 16-28). Many countries have been able to promulgate constitutions that include the right to adequate housing such as the constitutions of Portugal in 1976 as amended in1997 article 65, Brazil in1988, Cape Verde in 1992, and Chechnya in 2003, and before that the constitution of Mexico in 1917 as amended in 1983 article 4 "every family has the right to enjoy affordable and adequate housing..." ([2], P. 15-16, 40), as well as the constitution of Uruguayan in 1966 in article 45 "Every inhabitant of the country has the right to a decent home. The law shall seek to ensure hygienic and economical housing......." ([5] (reinst. 1985, rev. 2004), P.8); in addition, the constitution of South Africa in 1996 explicitly included the right to adequate housing and prohibits forced evictions, also the constitution of Venezuela in 1999, which included a comprehensive definition of adequate housing and established an organizational structure to secure the right to adequate housing for its citizens, especially for families with limited resources ([6], P.18,30,34). The reference to the right to adequate housing appeared in the Egyptian constitution amended in 2014 in article 78 ([7], P.26), and in October 2020, Egypt issued "Egypt housing strategy" in an attempt to promote affordable housing programs [8].

\section{The key aspects of the right to adequate housing}

The right to adequate housing should not be understood as the provision of a dwelling unit with four walls and a ceiling or considered as a commodity, rather it should be defined as a person's right to live someplace in security, peace, and dignity regardless of his or her income or access to economic resources. As indicated by The UN-CESCR in 1991, the term "adequate housing" should be defined in accordance with a variety of

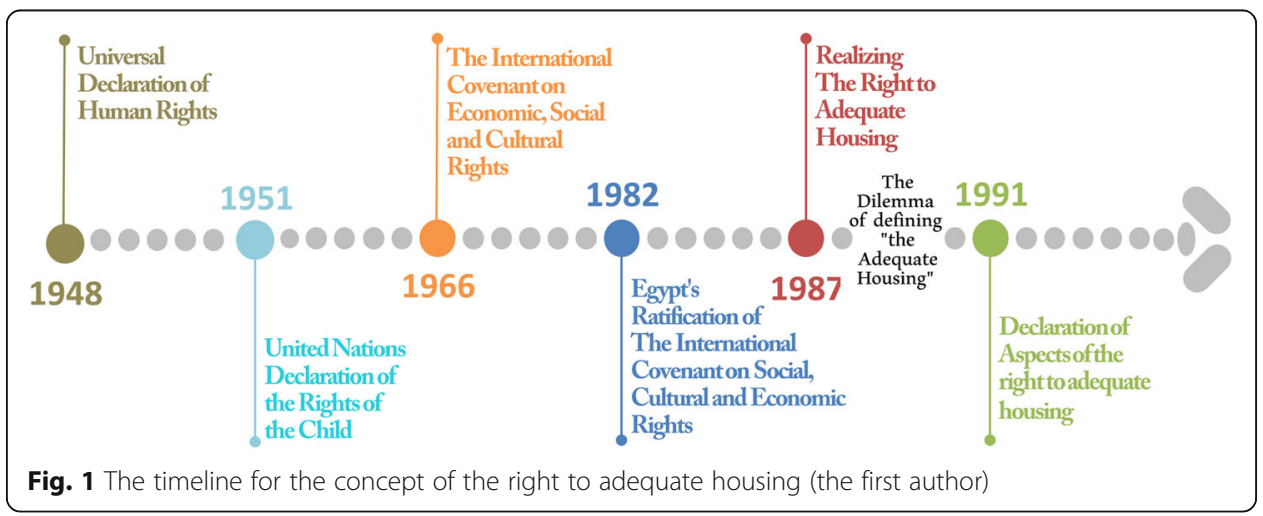


other considerations that have been included in seven key aspects ([1], P. 4) as illustrated in Fig. 2 below.

\section{Legal security of tenure}

Housing tenure takes many different forms, including renting, ownership, emergency accommodation, and informal status. Regardless of the type of tenure of the dwelling, everyone should enjoy a level of security in occupying the dwelling that guarantees legal protection against forced eviction and other threats or risks.

\section{Availability of services, materials, facilities, and infrastructure}

Adequate housing must have the basic facilities for health, security, comfort, and food; all beneficiaries of the right to adequate housing should have access to natural and public resources; clean and safe water; energy for cooking, heating, and lighting; sanitation; hygiene; waste disposal services; communications; and emergency services.

\section{Affordability}

The dwelling expenses should be of such a level that the fulfillment of other basic needs is not threatened or diminished. In general, the percentage related to housing costs should be equivalent to income levels, so governments should provide housing subsidies to those who cannot purchase affordable housing as well as finding means of real estate financing that makes the dwelling affordable. In addition, the renters should be protected from unreasonably high rental levels or rent increases by adopting appropriate means.

\section{Habitability}

Adequate housing must be habitable in terms of building structural safety, providing adequate space for living and protecting from weather changes or other health threats and disease vectors, and ensure that the health principles for dwelling prepared by the World Health Organization are applied.

The manner in which housing is constructed, the
building materials used and the policies in support of
them should allow for the appropriate expression of
cultural identity and diversity in housing.




\section{Accessibility}

Access to adequate housing should be available to all, especially marginalized and disadvantaged groups; therefore, the housing policies should consider the needs of these groups and ensure access to land for the benefit of the low-income groups of society along with affirmation of access to land as a right.

\section{Location}

Adequate housing should be in a location that provides access to health care services, schools, child care centers, and other social facilities as well as access to employment options where the traveling costs between housing and workplace can pressure on the budgets of the low-income groups. Besides, housing projects should not be built on polluted sites or close to pollution sources that threaten the residents' right to health.

\section{Cultural adequacy}

The housing construction and building materials should represent the social and cultural identities, as well as the housing construction technology; both need to be appropriate to community culture. Besides, the affordable housing programs should ensure diversity in housing types and patterns to fulfill the residents' social and cultural needs.

\section{Affordable housing programs in Egypt: case study}

Since the revolution of 1952, the government began establishing mass housing projects for government workers, and several social housing areas began to appear. The state is still building mega housing projects for the low-income level, recently known as the social housing programs. The history of affordable housing programs in Egypt can be divided into four phases interspersed with a transitional phase as a result of political circumstances in 2011, as shown in Table 1.

The amount of housing production, whether it has been produced or targeted, is supposed to fulfill the seven key aspects of adequate housing stipulated in the international covenant on economic, social, and cultural rights as Egypt is one of the parties in that covenant.

Table 1 The four phases of affordable housing programs in Egypt (The first author based on (Mortgage Finance Guarantee and Support Fund, 2018, page: 23-30))

\begin{tabular}{|c|c|c|c|c|}
\hline $\begin{array}{l}\text { Time } \\
\text { period }\end{array}$ & Project/program & $\begin{array}{l}\text { Duration of the } \\
\text { project }\end{array}$ & $\begin{array}{l}\text { Average annual } \\
\text { production } \\
\text { approximate } \\
\text { (in thousand units) }\end{array}$ & $\begin{array}{l}\text { Total output } \\
\text { during the period } \\
\text { (in million units) }\end{array}$ \\
\hline $1952-1981$ & Rental projects & 29 years & 37.8 & 1.1 million units \\
\hline $1982-2005$ & Various ownership projects & 23 years & 54.7 & 1.26 million units \\
\hline 2005-2011 & $\begin{array}{l}\text { The National Program for } \\
\text { Social Housing }\end{array}$ & 6 years & 70 (target 85) & $\begin{array}{l}608.087 \text { A } \\
\text { thousand units }\end{array}$ \\
\hline 2011-2013 & \multicolumn{4}{|c|}{$\begin{array}{l}\text { Completion of the National Housing Program with special requirements during a transitional } \\
\text { period as a result of political circumstances }\end{array}$} \\
\hline $\begin{array}{l}2013 \text { until } \\
\text { now }\end{array}$ & $\begin{array}{l}\text { The current social housing } \\
\text { program }\end{array}$ & 8 years until now & 200 & In progress \\
\hline
\end{tabular}




\section{Results}

In the light of the expert questionnaire results, this section presents the percentage of the realization of the seven key aspects of the right to adequate housing in the affordable housing programs in Egypt. Accordingly, it can be evaluated to which extent the key aspects of the right to adequate housing in affordable housing programs in Egypt have been realized.

By calculating the numerical average of the expert questionnaire results, the percentage of the realization of the seven key aspects at the four stages could be concluded as shown in Table 2, and is presented in Fig. 3.

Based on previous results, it is noticeable that

- Legal security of tenure aspect has been realized in all the affordable housing programs in Egypt providing secure tenure, whether for tenants or owners.

- Accessibility and Affordability aspects are still not sufficiently realized; despite the attempts of most of the governmental affordable housing programs in Egypt to make housing units easier to get and more affordable for the low-income groups, the requirements to apply for housing units still do not support the accessibility aspect, and the cost of the housing units is not affordable to the low-income groups.

- Habitability, Location, and Availability of services and infrastructure aspects have been realized and evolved with the progression of programs; as the standards of planning evolved in affordable housing programs in Egypt and the sites have become more supported by services and infrastructure, which increased habitability at the affordable housing projects and made them more populated. Despite the availability of infrastructure, the quality and efficiency of operation may vary among the different locations of the affordable housing projects.

- Cultural adequacy aspect is still not sufficiently realized; the affordable housing projects in all Egyptian regions still have the same housing prototypes in construction materials, unit areas, and housing unit design.

Table 2 The percentage of average realization of the seven key aspects in the affordable housing programs in Egypt (the first author)

\begin{tabular}{|c|c|c|c|c|}
\hline \multirow{2}{*}{$\begin{array}{l}\text { The seven } \\
\text { key aspects }\end{array}$} & \multicolumn{4}{|l|}{ Project/program } \\
\hline & $\begin{array}{l}\text { Rental projects } \\
\text { 1952-1981 }\end{array}$ & $\begin{array}{l}\text { Various } \\
\text { ownership } \\
\text { projects } \\
\text { 1982-2005 }\end{array}$ & $\begin{array}{l}\text { The National Program } \\
\text { for Social Housing } \\
2005-2011\end{array}$ & $\begin{array}{l}\text { The current social } \\
\text { housing program } \\
2013 \text { until now }\end{array}$ \\
\hline $\begin{array}{l}\text { Legal security of } \\
\text { tenure }\end{array}$ & $68.6 \%$ & $85.7 \%$ & $79.5 \%$ & $77.1 \%$ \\
\hline $\begin{array}{l}\text { Availability of services } \\
\text { and infrastructure }\end{array}$ & $62.9 \%$ & $68.1 \%$ & $65.0 \%$ & $74.3 \%$ \\
\hline Affordability & $63.8 \%$ & $57.3 \%$ & $61.9 \%$ & $59.9 \%$ \\
\hline Habitability & $56.2 \%$ & $60.0 \%$ & $62.4 \%$ & $81.1 \%$ \\
\hline Accessibility & $52.7 \%$ & $51.4 \%$ & $58.1 \%$ & $60.0 \%$ \\
\hline Location & $64.2 \%$ & $60.4 \%$ & $62.0 \%$ & $66.1 \%$ \\
\hline Cultural adequacy & $43.6 \%$ & $49.2 \%$ & $53.7 \%$ & $54.4 \%$ \\
\hline
\end{tabular}




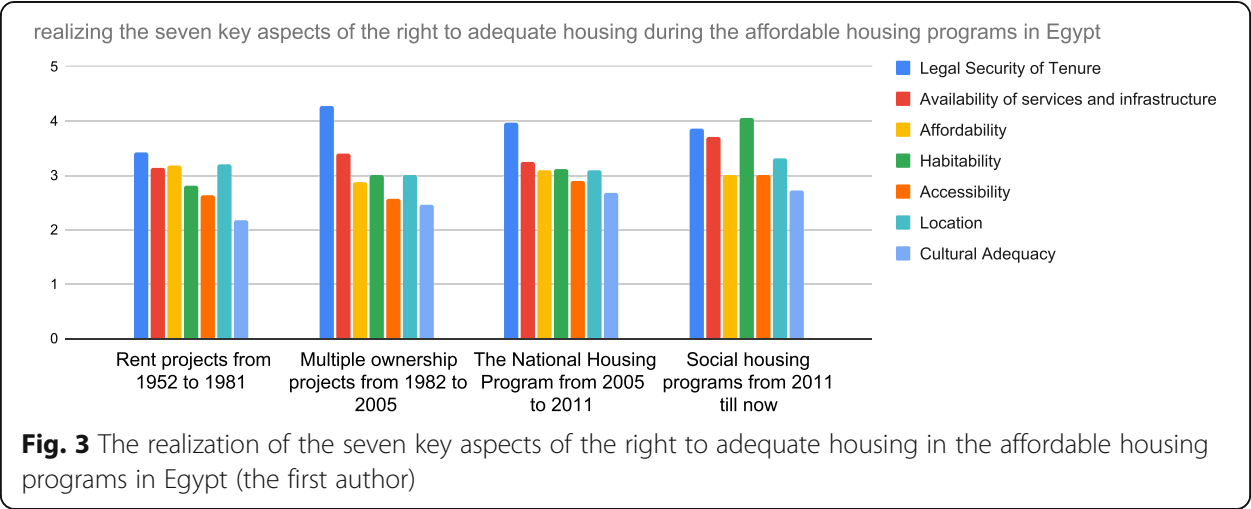

\section{Discussion}

This section discusses the realization of the key aspects of the right to adequate housing in affordable housing programs in Egypt during its four phases. The discussion is based on the data and information issued by the Egyptian housing sector official reports, as well as the analysis of the realization of the seven key aspects through calculating the numerical averages according to the experts' questionnaire results for a diverse sample of 57 academic and nonacademic experts in the field.

\section{Legal security of tenure}

The legal security of tenure is an essential aspect that has been provided in affordable housing projects. The experts' questionnaire indicated that it was the most fulfilled aspect during the four phases of affordable housing programs in Egypt. Although there was an increase in its realization during the period of the transformation to the ownership system instead of rent, it decreased slightly in the current social housing program as a result of the inauguration of the Social Housing Law [9], which provides the right to withdraw housing from beneficiaries by the law in case a set of conditions are violated ([3], P. 27, 47). Figure 4 shows the change in the realization of the secure tenure

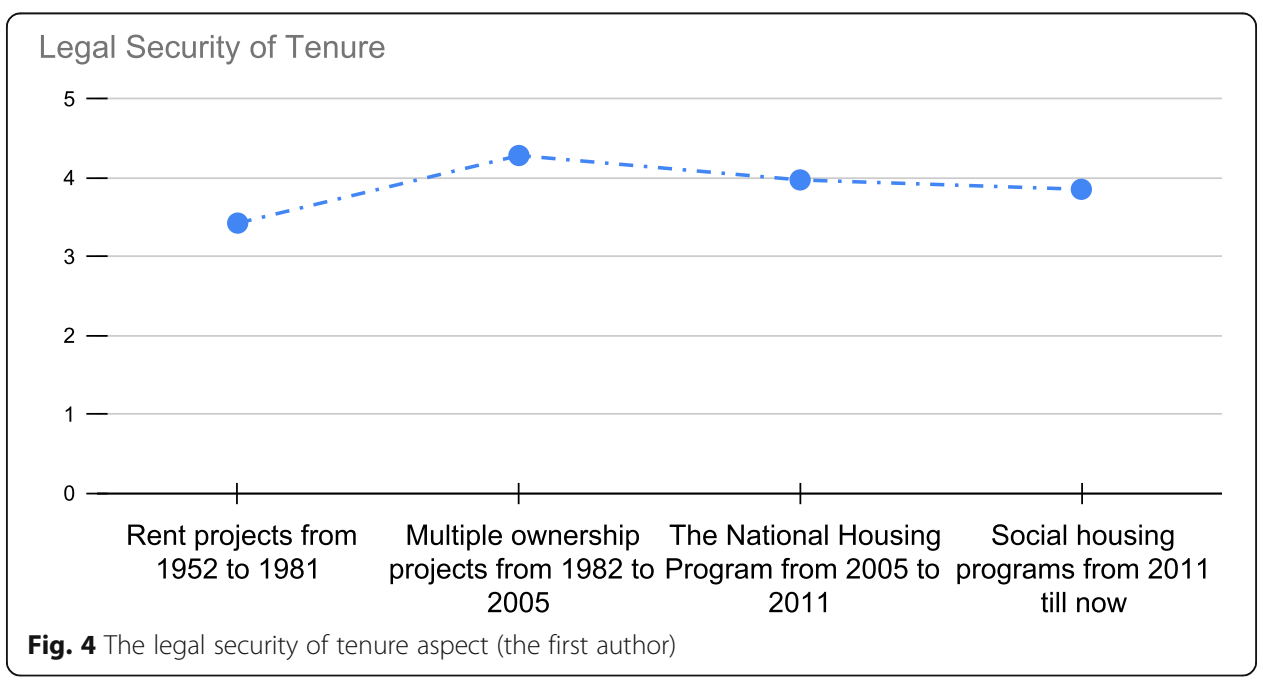


aspect during the four phases of affordable housing programs in Egypt, based on the results of the experts' questionnaire.

\section{Availability of services and infrastructure}

The availability of infrastructure during the affordable housing programs in Egypt is one of the aspects that have been fulfilled. The Egypt housing profile confirms that subsidized housing projects built in the new towns were provided, in most cases, with a good standard of basic off-site and on-site infrastructure (roads, water, electricity, telephones, and water-borne sewerage), public spaces, and social services, although on average the overall level of quality and operation was low and there were some cases of serious neglect, especially for older projects ([10], page: 38 ).

As shown in Fig. 5, the Availability of infrastructure aspect increases with the progress of the four phases of affordable housing programs in Egypt; according to the experts' questionnaire results, it is possible to notice the improvement in the availability of infrastructure with the progress in the phases of affordable housing programs; especially, it can be seen during the current social housing projects, as a result of setting some quality standards. As for the level of service availability, it is less achieved if compared to infrastructure.

\section{Affordability}

Before 2005, almost all of the families in Egypt were able to purchase governmental housing units as the down payments were affordable, and the required fixed installments did not exceed $25 \%$ of the household income at that time; besides, the installments are paid over a period of 30 years. After 2008, housing prices have rapidly increased ([11], Page: 51-77), which made it difficult for Egyptian families to find adequate housing at an appropriate cost, especially for vulnerable and marginalized groups (VMGs) and low-income groups. The current social housing projects work to provide housing units at a reasonable cost but housing units still not affordable to low-income groups.

Based on the experts' questionnaire results, it can be read that the decline in the ability to sustain the cost of housing during the Affordable housing programs is quite

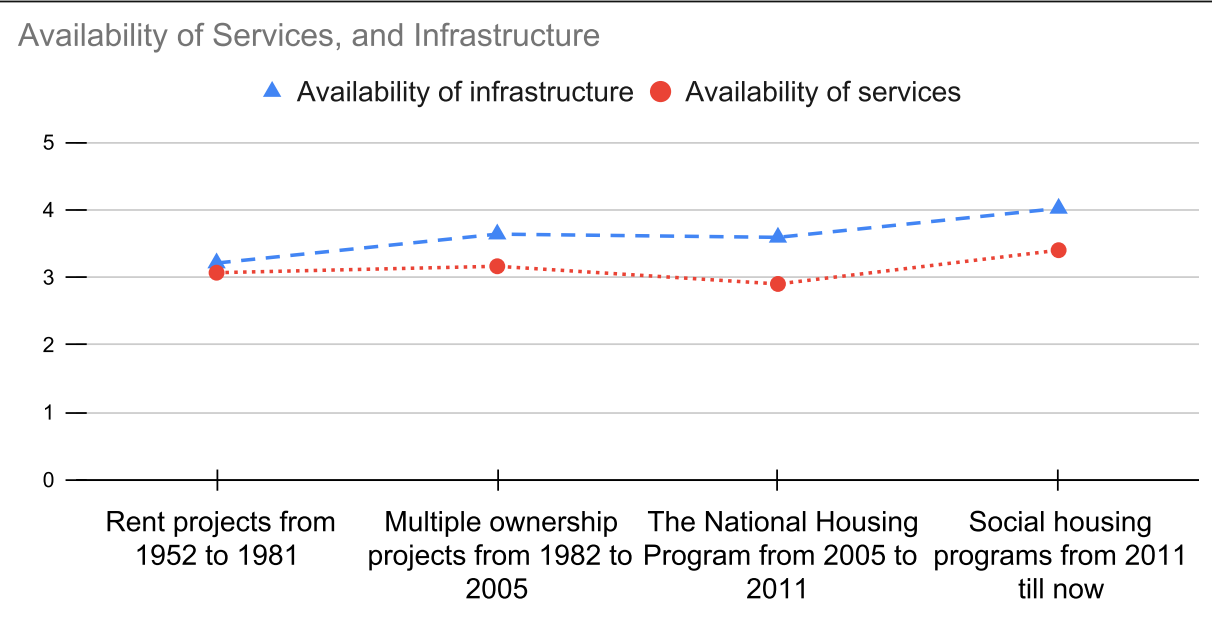

Fig. 5 The availability of services and infrastructure (the first author) 


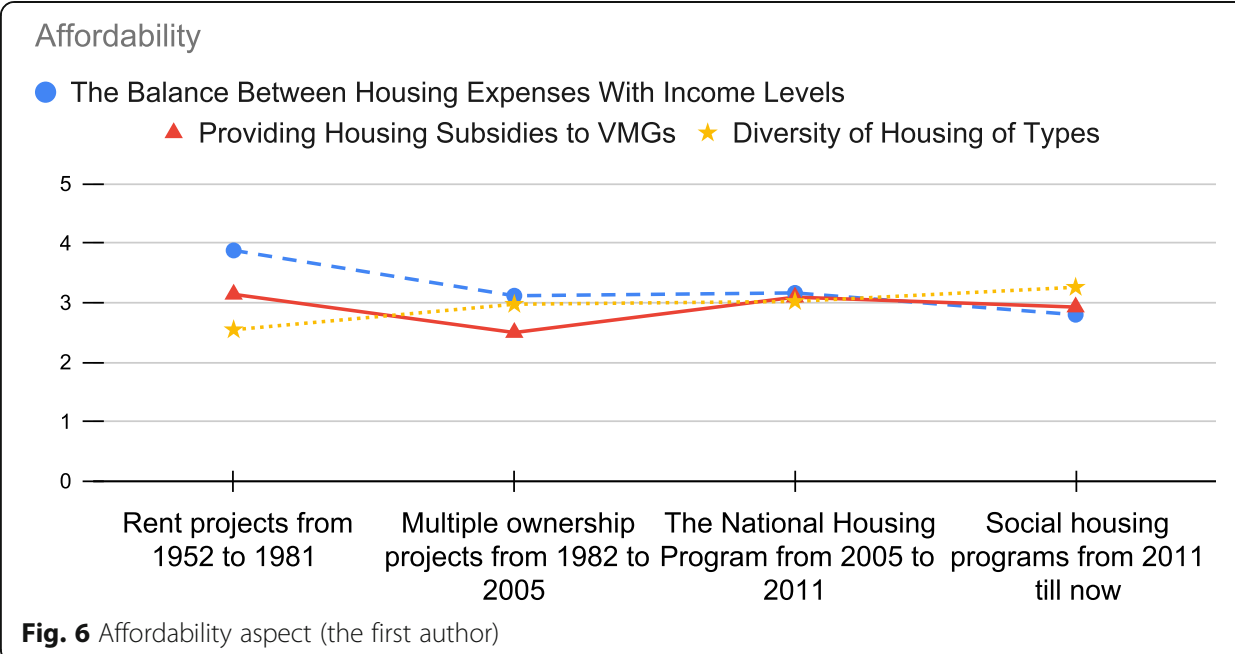

obvious, as shown in Fig. 6, whereas the diversity of housing units improves to suit all income groups.

\section{Habitability}

The quality of the affordable housing production in Egypt is generally appropriate in terms of structural safety and environmental and health suitability; as for the level of housing units' areas and their suitability to meet the living activities, it has become more adequate in recent projects.

In the National housing projects the housing unit area used to be $60 \mathrm{~m}^{2}$ then increased to $90 \mathrm{~m}^{2}$ during the current social housing programs. In the period from 1952 to 1981, the rental projects included small apartments in three- to five-story buildings with good ventilation and lighting, in the period from 1982 to 2005 the various ownership projects had high planning standards and included a variety of units: low-cost housing $\left(45 \mathrm{~m}^{2}\right)$, economical $\left(60 \mathrm{~m}^{2}\right)$, housing medium $\left(90 \mathrm{~m}^{2}\right)$, above-average $\left(125 \mathrm{~m}^{2}\right)$, and luxurious (greater than $125 \mathrm{~m}^{2}$ ). In the period from 2005 to 2011, the national housing project axes varied between plots of land and housing units with an area of $63 \mathrm{~m}^{2}$ in five-story buildings on average with good ventilation and lighting. The current social housing programs provide fully finished housing units with an area of $90 \mathrm{~m}^{2}$ in five-story buildings with good ventilation and lighting ([12], page: 23-30).

The experts' questionnaire results show that the building structural quality is most fulfilled in the aspect of habitability during the four phases of affordable housing programs in Egypt followed by environmental and health quality, and adequate spaces to meet the living activities, as shown in Fig. 7. In general, an improvement is noticed in the aspect of habitability as its indicators increase over time in affordable housing programs.

\section{Accessibility}

Most of the Egyptian affordable housing programs focus on providing housing with a subsidized ownership system, while some provide rental units or plots of land (site and 


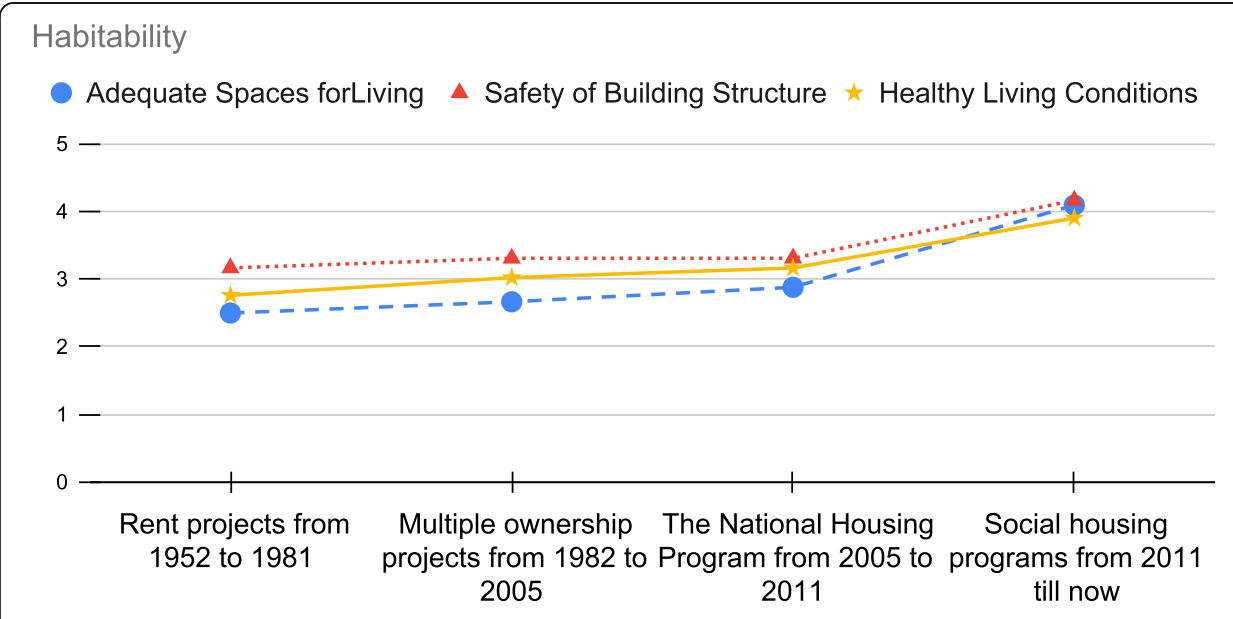

Fig. 7 Habitability aspect in affordable housing programs in Egypt (the first author)

services projects) with limited numbers. Until 2011, the affordable housing programs in Egypt rely on a traditionally paper-based process for having a housing unit within a lottery system, and during the current social housing programs applying relied on electronic submission and classification of applicants into segments according to specific priorities set by the Social Housing Fund taking into account VMGs as a priority ([12], page: $125,137,139)$.

In spite of the numerous housing programs in Egypt, and the increase in the current production rates of residential units, the aspect of accessibility for housing is still of concern as it did not reach the required level to keep up with population growth, as well as the low-income groups' limited accessibility as a result of the terms and conditions related to the allocation of units according to the family income. The current social housing programs have only been able to reach between 15 and $25 \%$ of the annual housing needs of the low-income groups ([10], page: 13). While the social housing programs only managed to serve $16 \%$ of the 160,000 households formed every year below the poverty line, the better-served governorates were Cairo, Suez, and Sharqia, with a

\section{Accessibility}

Accessibility to Housing Projects for Low-Income Groups

$\Delta$ Priority of VMGs in Obtaining Housing $\times$ Accessibility to land for Low-Income Groups $5-$

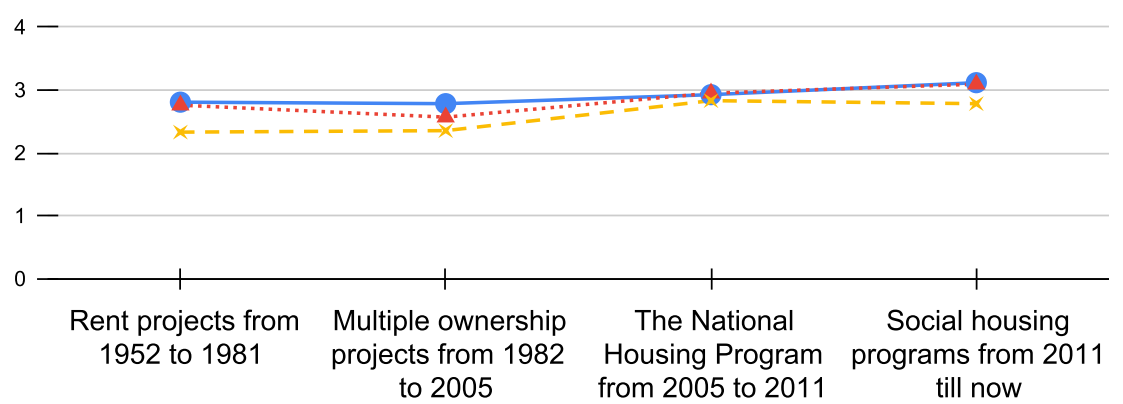

Fig. 8 Accessibility aspect in affordable housing programs in Egypt (the first author) 
coverage of $75 \%$ or over. However, in Upper Egypt, which has a high concentration of poverty, 7 out of 8 governorates there had coverage of $10 \%$ or less ([13], Section 4).

Experts' questionnaire results show that there is a weakness in the accessibility to housing units for low-income groups and VMGs, as well as a weakness in providing land to low-income groups through all affordable housing programs in Egypt, although there is a slight improvement in housing accessibility for low-income groups and VMGs during the current social housing programs as shown in Fig. 8.

\section{Location}

All government housing programs are based on the continued availability of costless remote desert land. In spite of many problems associated with these new housing complexes in remote desert locations, such as evidenced by their extremely slow increases in population, the dependence on the private sector in transportation and services provision, as well as limited connectivity between work location and housing project which costs people more time and money in terms of transporting between home and work ([10], page: xxii).

From the results of the experts' questionnaire, it is noticed that the distance of housing projects from the pollution sources has been achieved because most of the housing projects in Egypt are in remote desert locations. On the contrary, the connectivity between housing projects and work locations has not been achieved enough which appeared to increase costs in terms of time and money to transport between housing projects and work. Overall, the location aspect has been achieved averagely, and the level of its achievement has not changed in affordable housing programs till now, as shown in Fig. 9.

\section{Cultural adequacy}

Most of the affordable housing projects for the low-income groups are related to the use of standard housing models that do not reflect regional climatic and cultural differences, and which result in very uniform and rigid housing estates with

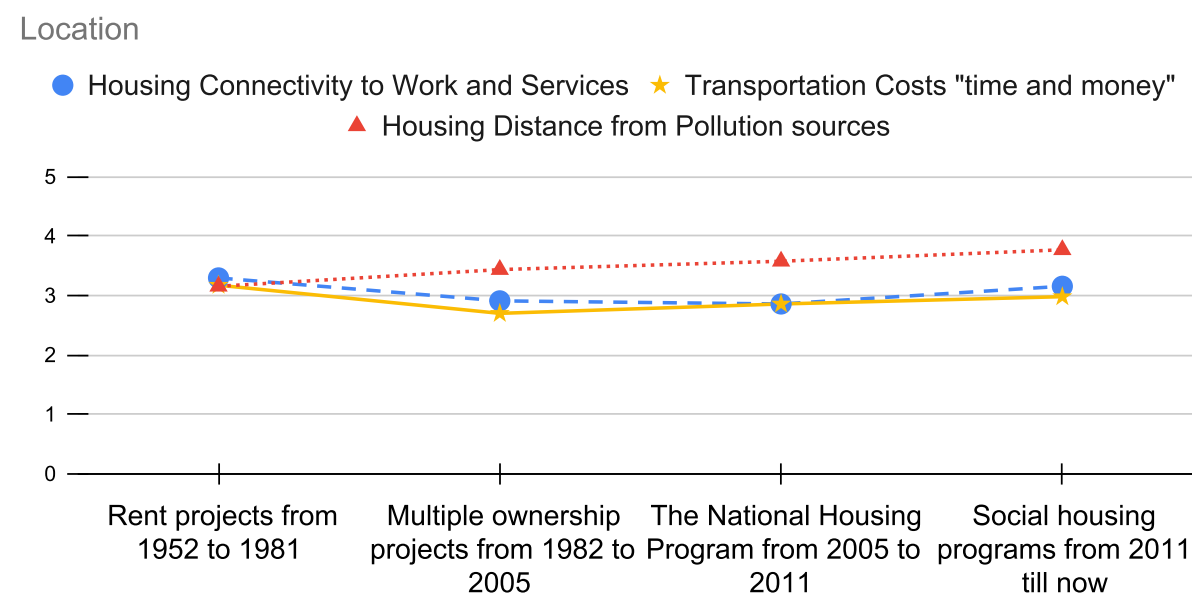

Fig. 9 Location aspect in affordable housing programs in Egypt (the first author) 


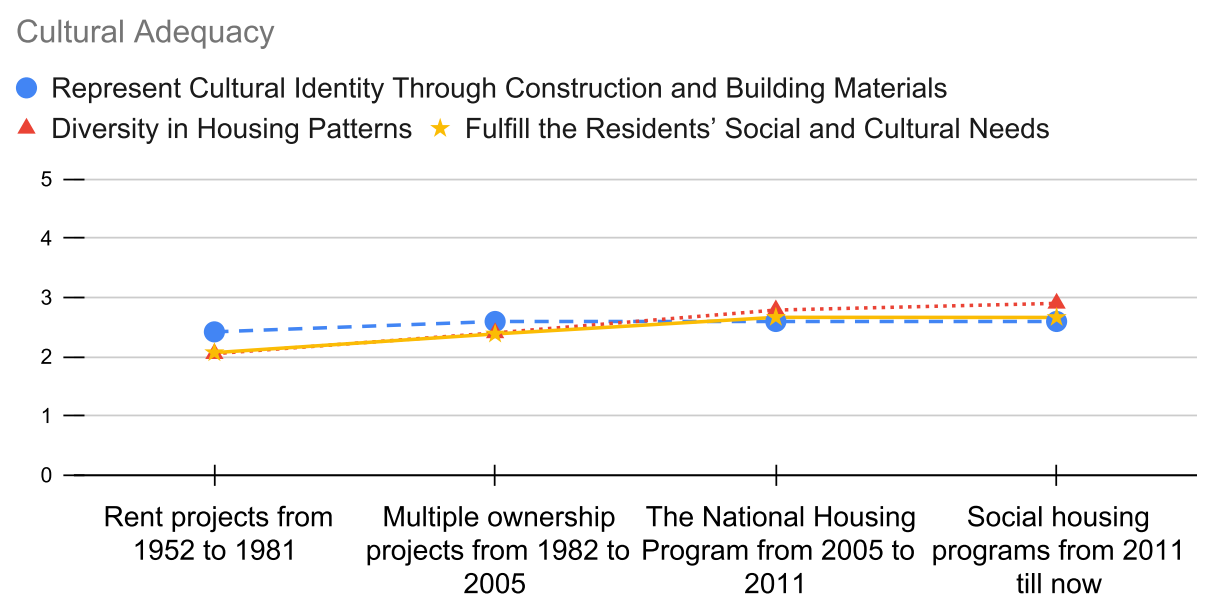

Fig. 10 Cultural adequacy aspect in affordable housing programs in Egypt (the first author)

neither mixed land usage nor a mixing of social classes, as a result of the criteria that determine the shape and area are based on statistical data of numerical averages for the families of the beneficiaries assuming the economic and social level of the beneficiaries ([10], page: xviii).

From the experts' questionnaire results, slight progress can be seen in the realization of the diversity in housing patterns while retaining the construction method and building materials, as shown in Fig. 10. Consequently, the aspect of cultural adequacy still did not achieve beyond the average during affordable housing programs in Egypt.

\section{Conclusions}

During affordable housing programs in Egypt, there has been a variation in the realization of the seven key aspects of the right to adequate housing. Some of them have been improved with the progression of the programs such as the aspects of legal security of tenure, habitability, location, and availability of services and infrastructure. On the contrary, the aspects of accessibility, affordability, and cultural adequacy are still not sufficiently realized.

Recently, with the increases in the production of social housing units and deal with housing units as a process, not as an end product, there is an opportunity to enhance the realization of the seven key aspects of the right to adequate housing. Therefore, further researches are needed to deal with housing programs as a participatory process based on fulfilling the seven key aspects of the right to adequate housing.

A future direction should focus on developing the requirements to achieve the right to adequate housing that is still not sufficiently realized. Future research can investigate the accessibility, affordability, and cultural adequacy of affordable housing programs in a specific case in Egypt. 


\section{Acknowledgements}

Not applicable

\section{Authors' contributions}

NM was a major contributor in writing the manuscript, analyzed, and interpreted the experts' questionnaire results and data regarding the realization of the seven key aspects of the right to adequate housing in governmental affordable housing programs in Egypt. RI contributed to identifying the experts to be interviewed. RR and DM contributed to reviewing the experts' questionnaire and the manuscript. All authors read and approved the final manuscript.

\section{Funding}

Not applicable. The research received no specific grant from any funding agency in the public, commercial, or not-forprofit sectors.

\section{Availability of data and materials}

The datasets generated and analyzed in the current study are available in the [Google/forms] repository, (https://docs. google.com/forms/d/19zG7IGel502yLpCoZsXU2EH5InrH9-5LE57VNIUw0oc/edit).

\section{Declarations}

\section{Ethics approval and consent to participate}

The authors declare that the manuscript is our original work. The ideas, views, innovations, and results presented in the above manuscript are totally ours unless otherwise referenced in the text. Works of others necessary for the development of ideas presented in this manuscript are clearly referenced within the text and accurately listed at its end; also, all participants gave informed consent to participate in the research.

\section{Consent for publication}

The authors declare that they consent for publication.

\section{Competing interests}

The authors declare that they have no competing interests.

Received: 13 April 2021 Accepted: 3 September 2021

Published online: 01 November 2021

\section{References}

1. Office of the High Commissioner for Human Rights (1991) General comment no. 4: the right to adequate housing, art. 11(1) of the Covenant, Adopted at the Sixth Session of the Committee on Economic, Social and Cultural Rights, OHCHR, Contained in Document E/1992/23. Available via: https://www.refworld.org/pdfid/47a7079a1.pdf. Accessed 20 Mar 2021. Accessed 20 July 2021

2. UN Office of the High Commissioner for Human Rights (2014) Fact sheet no.21: the human right to adequate housing, Fact Sheet No.21/Rev.1, OHCHR. Available at: https://www.ohchr.org/Documents/Publications/FS21_rev_1_Housing_en. pdf. Accessed 20 July 2021

3. Shawkat, Y. (2014) "Housing policy in Egypt: between the continuation of the policies of the past and the establishment of fair policies for the future", Egyptian Initiative for Personal Rights. Available via: https://eipr.org/sites/default/files/ reports/pdf/housing_policies_in_egypt-study.pdf. Accessed 20 July 2021

4. United Nations General Assembly Resolutions (1987) The General Assembly of Nations resolution, United Nations General Assembly Resolutions report, UNGA, P.234-235. Available via: http://www.worldlii.org/int/other/UNGA/1987/. Accessed 20 July 2021

5. Uruguay's Constitution of 1966, reinstated in 1985, with amendments through 2004 (2012), article45, P.8. Available via: https://www.constituteproject.org/constitution/Uruguay_2004.pdf?lang=en. Accessed 20 July 2021

6. Amnesty International (2010) HAKI ZETU, ESC rights in practice, the right to adequate housing, Special Programme on Africa (SPA), Amnesty International Netherlands, Hakijamii Economic and Social Rights Centre, Kenya, P.18,30,34. Available via: https://www.amnesty.nl/content/uploads/2017/01/the_right_to_adequate_housing.pdf?x40553. Accessed 20 July 2021

7. Egypt's Constitution of 2014 (2014), Article (78), Constitution of the Arab Republic of Egypt, P.26. Available via: https:// www.constituteproject.org/constitution/Egypt_2014.pdf. Accessed 20 July 2021

8. United Nations for Human Settlements, UN-Habitat (2020) Egypt housing strategy, United Nations Human Settlement Programme Regional Office of Arab States Egypt Office. Available via: https://unhabitat.org/sites/default/files/2020/09/ egypt_housing_strategy.pdf. Accessed 20 July 2021

9. The Egyptian official newspaper (2018) Law no. 93 of 2018, issuing the social housing and real estate finance support laws, art. 4, issue 33, page: 35-52. Available via: https://rern.gov.eg/files/8d9_155536059795540.pdf. Accessed 20 July 2021

10. United Nations Human Settlements Programme (UN-Habitat) (2016) Egypt housing profile, United Nations Human Settlement Programme, Regional Office of Arab States Egypt Office, and Housing Unit - Ministry of Housing, Utilities and Urban Communities (MHUUC). Available via: https://unhabitat.org/sites/default/files/download-manager-files/152 5977522wpdm_Egypt\%20housing\%20EN_HighQ_23-1-2018.pdf. Accessed 20 July 2021

11. The United States Agency for International Development (2007) Review of Egyptian subsidized housing programs and lessons learned, final report, Technical Assistance for Policy Reform II, TAPR II, USAID/Egyp Policy and Private Sector Office, Page: 51-77. Available via: https://pdf.usaid.gov/pdf docs/PA00WH8D.pdf Accessed 20 July 2021 
12. Mortgage Finance Guarantee and Support Fund (2018) The data and statistics from Achievements report of Mortgage Finance Guarantee and Support Fund, and the Social Housing Fund, published report, Egypt. Available via: https://shmff. gov.eg/wps/wcm/connect/4e9473e1-788a-44a7-b030-d1c95fce229c/2018_compressed.pdf?MOD=AJPERES\&CONVERT_ TO=url\&CACHEID=ROOTWORKSPACE-4e9473e1-788a-44a7-b030-d1c95fce229c-nlBOAll. Accessed 20 July 2021

13. The Built Environment Observatory (2018) A million units for whom? Six facts about the Social Housing Project, facts sheet, part of the Egypt state of housing 2017 series, section 4: is the SHP needs-based?, BEO, Egypt. Available via: http://marsadomran.info/en/facts_budgets/2018/05/1543/. Accessed 20 July 2021

\section{Publisher's Note}

Springer Nature remains neutral with regard to jurisdictional claims in published maps and institutional affiliations.

Submit your manuscript to a SpringerOpen ${ }^{\circ}$ journal and benefit from:

- Convenient online submission

Rigorous peer review

- Open access: articles freely available online

- High visibility within the field

- Retaining the copyright to your article 